\title{
EXCLUSION OF AVIATION RISKS FROM LIFE INSURANCE CONTRACTS
}

RIsK selection is crucial to profitable operation of the life insurance business, and premium rates for accepted applicants must be related to the risk insured. ${ }^{1}$ With the advent of aviation, life insurance companies sought to avoid liability for deaths due to flight by excluding aviation hazards from policy coverage. ${ }^{2}$ The aviation exclusion rested on the premise that aviation risks were either too great to be covered at standard premium rates or so unpredictable that no coverage could be granted. ${ }^{3}$ And companies feared that many people might take out large policies immediately before embarking upon an aviation career. ${ }^{4}$

The mushrooming of aviation into a major industry ${ }^{*}$ led to an increasing

1. Johnson, Life Insurance in the Development of Aviation, WEEKLY UNDERWRTtER 1329 (Nov. 28, 1953). Since premiums are small in relation to the company's liability, the conditions of liability are vital. An ideally planned and managed insurance enterprise will receive sufficient premiums from all policy holders exposed to similar risks to pay losses incurred by that group plus overhead expenses and reasonable profits. If a person subject to greater risks is allowed to participate with those exposed to lesser risks, either the latter will pay more than they should or the insurer will lose money. See Patterson, Essentials of Insurance Law 199 (1935). When dealing with an extra-hazard such as aviation, the insurer may: (1) decline the application; (2) accept the application but exclude the hazard; (3) accept the application but limit coverage of the hazard to a fixed amount of exposure; (4) accept both application and hazard but demand increased premiums; (5) accept the entire application at standard rates. See Institute of Life Insurance, Life Insurance Fact Book 43, 44 (1953).

2. Even before the Wright Brothers made their historic flight in 1903 , life insurance policies had recognized the hazard of flight. As early as 1878, "engagement in aeronautic voyages or flight was prohibited. . . ." Johnson, supra note 1, at 1329.

3. See Crowdus, Aviation Insurance, 2 J. Air L. 176, 177 (1931).

The first rash of aviation insurance broke out toward the end of World War I and extended into the 1920 's. Since adequate actuarial statistics were unavailable to guide the insurer in selecting risks prior to 1928 , acceptance of these risks violated sound underwriting principles, note 2 stupra, and could only result in disaster for companies with small premium reserves. The first data on aviation risk experience, which became available in 1930, showed that aviation involved greater hazards than any other means of transportation. The death rate at that time was 24.1 per $100,000,000$ passenger miles-sixty times the rate for 1952. Eastern Underwriter, Oct. 6, 1950, p. 52. The earliest exclusionary clauses proved inadequate, Pacific Mutual Life Ins. Co. v. Van Fleet, 47 Colo. 400, 107 Pac. 1087 (1910), and drove companies to seek more effective provisions. For the impact of state statutes on the enforceability of aviation exclusion clauses, consult Fischbach, Validily of Aviation Risk Exclusion Riders-A State-by-State Study in Procendngs, 46tu ANn. Meeting of the Legal Section of the American Life Convention 102 (1953).

4. See Johnson, supra note 1 , at 1329.

5. In 1928, 1,451 persons were employed by the airlines, 294 as pilots or crew members and 1,157 in other capacities. CAA, Statistical HANDBOoK of Civil Aviation 29 (1945). In 1952, the airlines employed nearly 100,000 persons in all capacities and utilized more than $\$ 1$ billion in assets. American Aviation, Apr. 27, 1953, pp. 13, 18. Only 1,036 airports and landing fields were in use in 1927, CAA, HANDB00K, op. cit. supra at 11, while more than 6,000 were in operation in 1951. American Aviation, supra at 12. In 1929, 173,405 pas- 
number of deaths in this excluded category. ${ }^{\circ}$ And, as ever more beneficiaries ran afoul of aviation exclusions, judicial hostility toward these clauses increased: courts tended increasingly to favor the policy of granting coverage to the maximum number of persons over that of allowing insurers to protect themselves by restrictive wording.

Today, travel on regularly scheduled airlines is safer than transportation by automobile, ${ }^{8}$ and is generally accepted as an ordinary incident of commerce and recreation. ${ }^{9}$ But many presently outstanding as well as newly

sengers were flown 45,667,334 passenger miles, but in 1952, approximately 30,000,000 passengers flew 15,54\$,247,000 miles. Id. at 3.

6. The average number of deaths in civil aviation accidents for the five year period, 1933 to 1937, was 333, while the total number of deaths from this cause in 1952 was 843. Chicago National Safety Counct, Accident Facts 75 (1953).

7. E.g., Massachusetts Protective Ass'n v. Bayersdorfer, 105 F.2d 595 (6th Cir. 1939); Marks v. Mitual Life Ins. Co., 96 F.2d 267 (9th Cir. 1938); Gits v. New York Life Ins. Co., 32 F.2d 7 (7th Cir. 1929).

s.

Coxiparison of Transportation Aocinent Deatu Rutes

1951

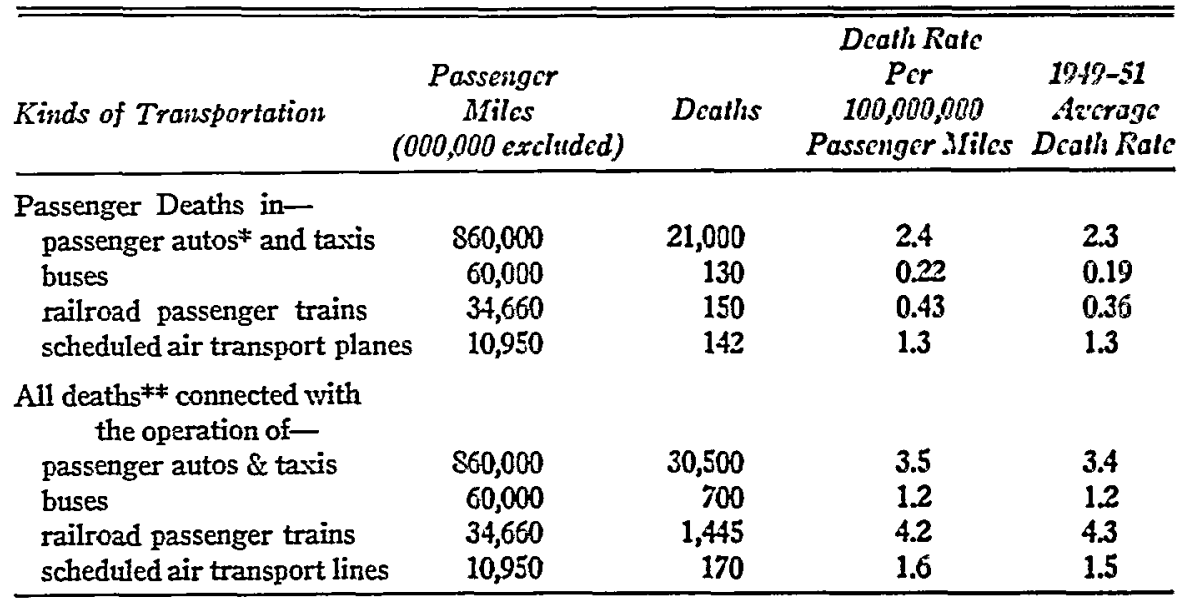

Source: Railroad data from Interstate Commerce Commission; Airplane data from Civil Aeronautics Board; Motor Vehicle data, approximation by National Safety Ciuncil based on data from state traffic authorities, Bureau of Public Rozds and Bus Transportation (magazine). Compilation prepared by Institute of Life Insurance.

* Drivers of passenger autos are considered passengers.

** All persons-pedestrians, trespassers, and thieves, as well as passengers-lvilled in the operation of the vehicles are included.

9. General aviation aircraft are used for business purposes, for flight instruction, pleasure and sport, advertising, power and pipeline patrol, and a variety of agricultural uses, such as dusting, spraying, fertilizing and seeding. CAA, Staristical Hn:ridoos or CivuL Aviation 348 (1953). Domestic airline passenger travel has grown to the point where it exceeds Pullman train travel by three billion passenger miles, and constitutes $57.3 \% \mathrm{c}$ of the combined total for both types. Id. at 59. And domestic scheduled airline carriers alone flew nearly 250 million air cargo ton miles in 1952. Id. at 65 . 
issued life insurance policies contain aviation exclusion clauses ${ }^{10}$ or command stepped-up premium rates. ${ }^{11}$ Compulsory military service, together with the expansion of the Air Force, may render thousands of policies potentially worthless $^{12}$ as well as make it difficult for applicants of draft age to obtain coverage.

While all persons who flew were at first held to be within the purview of aviation clauses, courts soon began to make distinctions. ${ }^{13}$ The decisions followed dual paths-one for pilots and crew members, another for passengers. Currently, further distinctions are drawn between passenger flight in a private plane and on a regularly scheduled commercial airliner. A reappraisal of past rulings in light of current aviation statistics is necessary to guide a policy suitable to the business needs of the insurer and the fair demands of the policy-holder.

\section{Pilot and Crew}

\section{Judicial Views}

Regardless of possible defenses based on the policy's wording, ${ }^{14}$ courts have, with rare exceptions, held that beneficiaries of a pilot or of crew members

10. Three types of exclusions in general use circa 1936 were: (1) "Death as a result of service, travel, or flight, in any species of aircraft, except as a farc-paying passenger, is a risk not assumed under this policy." (2) "Death as a result, directly or indirectly, of service, travel, or flight in any species of aircraft, except as a fare-paying passenger on a licensed aircraft piloted by a licensed passenger pilot on a scheduled passenger air service regularly offered between specified airports, is a risk not assumed under this policy." (3) "Death as a result, directly or indirectly, of service, travel, or flight in any species of aircraft is a risk not assumed under this policy." See Glass, Aeronantic Risk Exclusions in Life Insurance Contracts, 7 J. AIr L. 560, 585 (1936). "Death as a result of service, travel, or flight in any kind of aircraft, except as a fare-paying passenger on an aircraft operated by an air carrier licensed and under governmental supervision, is a risk not assumed under this policy." is a clause added to policies issued circa 1947 by the Life Insurance Department of the Dime Savings Bank of Brooklyn, New York. For the extent to which exclusions of this type are still in use see Institute of LIFE Insurance, Life Insurance Fact Book 29 (1950).

11. Ibid. The overall selection of risk practices includes limitations such as the maximum hours of flight covered and maximum policy value, and outright rejections along with $\mathrm{cx}$ clusions.or increased rates. For a recent study of the practices of 100 insurance companies regarding applicants who contemplate travel, see ibid.

12. See, e.g., Durland v. New York Life Ins. Co., 186 Misc. 580, 61 N.Y.S.2d 700 (Sup. Ct. 1946) (recovery denied where applicant did not intend to fly but was later killed in Air Force plane crash).

13. See, e.g., Gits v. New York Life Ins. Co., 32 F.2d 7 (7th Cir.), cert. denied, 280 U.S. 564 (1929). See also discussion at page 700 infra.

14. See clauses in note 10 supra. The more typical clauses in very early use stated that "persons engaged in the following classes of business or employment shall not be admitted: ... balloonists, aviators, aeronauts, aeroplanists . . "Sovereign Camp Woodmen of the World v. Compton, 140 Ark. 313, 215 S.W. 672 (1919) ; or ". . . no accidental death benefits shall be payable if the death ... resulted from ... having been engaged in aviation. . . ." Taylor v. Prudential Ins. Co., 142 Misc. 94, 253 N.Y. Supp. 55 (Sup. Ct. 1931). 
are barred from recovery by aviation clauses. ${ }^{15}$ The rationale of these cases is uncomplicated: The parties have signed a contract which both are presumed to have understood; this contract indicates an intent to exclude from coverage any and all pilot or crew member deaths due to flight, and the court will honor the intention. ${ }^{16}$ However, the Second Circuit's 1951 decision in Broidy $z$. State Mutual Life Assur. Co. ${ }^{17}$ sheds doubt upon the continued uniformity of this rule. The insured, an Air Force officer, was killed while flying in the Indianapolis Air Races. His application form had given no hint of an aviation exclusion. But the policy issued by the company excluded the risk of flight. This policy was accepted and paid for by the insured without actual knowledge of the restriction. ${ }^{18}$ Recovery was allowed to avoid "the absurdity that an air force officer should take out insurance of so little value as this would otherwise have been to him."19

Since this "absurdity" can arise any time a pilot applies for insurance, the Broidy case probably requires actual notice to professional fliers where policies are conditioned by a flight risk clause..$^{20}$ Moreover, the implications of the

15. See, e.g., Provident Life \& Accident Ins. Co. v. Anderson, 166 F.2d 492 (4th Cir.), cert. denied. 334 U.S. 846 (194S) ; Day v. Equitable Life Assur. Sac., 83 F.2d 147 (10th Cir.), cert. denied, 299 U.S. 548 (1936) ; Missouri State Life Ins. Co. v. Martin, 188 Ark. 907, 69 S.W.2d 1081 (1934) ; Beveridge v. Jefferson Standard Life Ins. Co., 120 W. Va 256, 197 S.E. 721 (1938). Contra: Charette v. Prudential Ins. Co, 202 Wis. 470, 232 N.W. S4S (1930). Later cases have indicated that this minority holding is probably not good law. E.g., Irwin v. Prudential Ins. Co., 5 F. Supp. 382 (E.D. Mich. 1933); Blonski v. Bankers Life Co., 209 Wis. 5, 243 N.W. 410 (1932).

The term crew, as used in an aviation accident policy, includes those who assist in the handling of airplanes on the ground as well as those who assist in their operation during flight and may apply to a single person. Preferred Acc. Ins. Co. v. Rhodenbaugh, 160 F.2d 832 (6th Cir. 1947) (stewardess considered a crewmember though no passengers aboard). See also Miner v. Western Casualty and Surety Co., 241 Iowa 530, 11 N.W.2d 557 (1950) ; State ex rel. Mutual Life Ins. Co. v. Shain, 344 15o. 276, 126 S.W.2d 181 (1939), quashing opinion in Hansen v. Mutual Life Ins. Co. of New York, 118 S.IW.2d 505 (1938).

16. The courts characterized pilot and crew members as having peculiar and special skills, which were utilized with such frequency as to approximate an occupation. It followed that they were engaged in aviation or aeronautics and came within the furview of such exclusionary language. This was also true where forlicipating in aviation or aeronautics was the excluded conduct as both terms coalesced when applied to a pilot or crew member. Mass. Protective Assoc. v. Bayersdorfer, 105 F.2d 595 (6th Cir. 1939); Missouri State Life Ins. Co. v. Martin, 18S Art 907, 69 S.W'.2d 1081 (1934); Masonic Acc. Ins. Co. v. Jackson, 200 Ind. 472, 164 N.E. 628 (1929).

17. 186 F.2d 490 (2d Cir. 1951).

18. Id. at 493 .

19. Ibid. The court substantiated its ruling by noting that under New York law the mere omission to read or know the contents of a written instrument does not bar relief by way of reformation thereof on account of mistake or fraud. As to the element of notice so heavily stressed, see N.Y. Insuraxce LAw $\$ 142(1)$ (1949): "Every policy of life ... insurance... delivered or issued in this state shall contain the entire contract between the parties, and nothing shall be incorporated therein by reference . . . unless a copy thereof is endorsed upon or attached to the policy or contract when issued."

20. New York courts will strictly enforce the notice requirements of N.Y. I:ss. LAw $\S 142$ (1) (1949). In Blatz v. Travelers Ins. Co., 272 App. Div. 9, 13-14, 6\$ N.Y.S.2d 
decision may extend beyond mere rejection of the earlier assumption that the assured knows what he is signing. Under traditional doctrines, the court would have reached the opposite result by finding that Broidy's application was an offer to which the company made a counter-offer containing the exclusionary clause, and that Broidy's payment of the first premium was an acceptance of the counter-offer ${ }^{21}$ regardless of whether he, in fact, read the policy.22 By seizing upon lack of notice to invalidate the exclusion, and thus rejecting the view that a man is held to what he signs, the opinion may indicate a desire to liberalize recovery in the case of pilot deaths. If this be so, courts may increasingly examine the circumstances surrounding issuance of life insurance policies to strike down exclusions of pilot deaths. ${ }^{23}$

The rule that pilots are embraced by aviation clauses is further restricted by the importation of proximate cause doctrines. Thus, where death was caused by risks other than those of flight, recovery was allowed. In Bull v. Sun Life Assur. Co., ${ }^{24}$ insured was killed by enemy strafing after safely crashlanding in the ocean. Recovery was granted on the grounds that death was a direct result of a "risk of war," and aviation was found to be only a contributing cause. ${ }^{25}$ While some courts accept this view, ${ }^{20}$ the majority reject it on

801, 805 (4th Dept. 1947), the policy itself provided in its general provisions: "Entire Contract-This instrument and the application constitute the entire contract between the parties." A rider embodying an aviation exclusion was issued. The original copy of the rider was signed by the insured and returned to the company; the insured's copy was blank, and was not signed or physically attached to the policy. A rubber stamp on the front of the policy stated: "To be modified by an attached rider." The court ruled that the rubber stamp was not sufficient and granted recovery. But if. Good v. Metropolitan Life Ins. Co., $166 \mathrm{~Pa}$. Super. 334, 71 A.2d 805 (1950) (aeronautics rider need not be physically attached to the policy in order to be valid where insured specifically atcepted rider).

21. Metropolitan Life Ins. Co. v. Whitler, 172 F.2d 631, 633 (7th Cir, 1949): "Th1" law is well settled that an application for life insurance itself is not the contract, but is a mere offer or proposal fon a contract of insurance. It is merely a step in the creation of the insurance contract. ... And where the insurance company tenders a policy at variance with the application, the tender constitutes a counter-offer and upon acceptance of the policy by the insured, there is a meeting of the minds and the policy becomes the contract between the insured and the insurance company."

22. "A contract for insurance is no different than any other contract. The insurance company is entitled to have its contract enforced by the courts as written." Drilling v. New York Life Ins. Co, 234 N.Y. 234, 241, 137 N.E. 314, 316 (1922). "No rational theory of contract can be made that does not hold the assured to know the contents of the instrument to which he seeks to hold the other party." Lumber Underwriters of New York v. Rife, 237 U.S. 605, 609 (1915). See Restatement, Contracts $\$ 70$ (1932).

23. Courts have used even more strained interpretations to allow recovery. See page 701 infra.

24. 141 F.2d 456 (7th Cir. 1944).

25. Id. at 459. No clauses excluding war risks were written into this or other military cases discussed infra.

26. Boye v. United Services Life Ins. Co., 168 F.2d 570 (D.C. Cir.), cort. denicd, 335 U.S. 828 (1948) ; Riche v. Metropolitan Life Ins. Co., 193 Misc. 557, 84 N.Y.S.2d 832 (Sup. Ct. 1948) ; Temmey v. Phoenix Mutual Life Ins. Co., 72 S.D. 387, 34 N.W.2d 833 (1948). 
the grounds that death resulted from a risk ordinarily associated with the particular hazard: aviation. ${ }^{27}$ Thus recovery was denied in Grecn v. Miubual L. I. $\mathrm{Co}_{.}{ }^{28}$ where the insured died of exposure and drowning after a crashlanding on a lake.

Importation of causation rationales in this context contributes little to solution of the coverage problem. It is true that if the insured pilot or crew member had not boarded his plane for a particular combat mission, he never would have been fired upon. Since "the airplane brought him to where the bullet hit him," his death can be considered the direct result of flight. However, absent the combat mission and the bullet, the flight would not have proved fatal. In that sense, death might be considered the direct result of ator. A hopeless conflict results which serves no useful purpose in determining the coverage of pilot and crew. ${ }^{23}$

\section{The Passenger}

In applying flight risk clauses to passengers, courts were from the outset thrown into a linguistic muddle. ${ }^{30}$ With few exceptions, these early decisions

27. "To cut the chain of causation at the point of landing the aircraft on the water would be unreasonably to limit the purview of the phrase "indirect result," in a world where the variety of fatalities stemming from flight is only too well lnown." Rossman v. Metropolitan Life Ins. Co., 71 F. Supp. 592, 595 (D. Me. 1947) (insured drowned after a safe emergency landing at sea). See United Commercial Travelers v. King, 161 F.2d 108 (4th Cir.), aff'd, 333 U.S. 153 (1947) (insured, freed himself from the plane, but died from exposure); Neel v. Mutual Life Ins. Co., 131 F.2d 159, 161 (2d Cir. 1942) (insured appeared to have drowned after safe crash landing).

28. 144 F.2d 55 (1st Cir. 1944).

29. Compare Boye v. United Services Life Ins. Co., $16 S$ F.2d 570 (D.C. Cir.), cert. denied, 335 U.S. S2S (1948) (recovery granted where insured believed lost as a result of anti-aircraft fire), with Thoma v. New York Life Ins. Co., 30 North. 369 (Pa. 1946) (recovery denied under almost identical circumstances). Allowing recovery on the ground that war rather than flight led to the insured's death would seem strained except in cases of flight under intense enemy fire. For a defense of the proximate cause theory sce Moriarity, Judicial Interpretation of Aziation Rishs Exclusion Clouses, 25 Norne Dasse. LAw. 695, 711 (1950).

30. Price v. Prudential Ins. Co., 98 Fla. 1044, 124 So. 817 (1929) is an example of such preoccupation with grammatical niceties. "The phroses (from having been engaged in aviation or submarine operations, or in military or naval service in time of var . ..) are between two semi-colons. They (aviation or submarine operations; military or naval service) are joined without punctuation by the words 'or in,' and the last phrase is followed without punctutation by the words in time of war'... . The phrases contained different moums... . The use of the two vords 'or in' to join the two phrases describing materially different hazards indicates that the two phrases do not and were not intended to express a single or continuous thought, and that the qualifying phrase 'in time of war' was intended to refer to the next preceding phrase, "military or naval service," and not also to the more remote phrase "aviation or submarine operations." "Id. at 1045,124 So. at 817. In Charette v. Prudential Ins. Co., 202 Wis. 470, 232 N.W. S4S (1930), the court affirmed a recovery on the main contention that the adz'crbial plirase 'in time of war' referred to the predicate phrase 'having been engaged in' and thus excluded all peacetime aviation from the exception. 
made no attempt to distinguish the death of a guest in a private plane from that of a fare-paying passenger ${ }^{31}$ on a scheduled commercial flight. Nor was the latter situation set apart from the death of a paying passenger on a non-scheduled flight.. ${ }^{32}$ Instead, widespread judicial haggling developed over the proper application of such terms as "engage in," "participate in," and "aeronautics." 33 The original area of conflict concerned the problem of whether a passenger "engaged in," as distinguished from "participated in," aeronautics.

When the words "engaged in aeronautics" were used, courts allowed recovery on one of two grounds. Since hundreds of people were actually employed as pilots and crew members by aviation corporations, ${ }^{34}$ courts felt that "engaging" suggested a continuity of action characteristic of an occupation, rather than the single isolated act of riding in an aircraft as a paying passenger. ${ }^{35}$ Consequently they reasoned that the clause evinced no intention of the parties to exclude occasional as distinguished from occupational fight. The alternate but closely related doctrine that the clause was ambiguous and must, therefore, be construed against the insurer was advanced in Patcrs $v$. Prudential Life Ins. Co. ${ }^{36}$ Since words and phrases used in insurance policies should be construed according to their meaning in ordinary speech, hairsplitting distinctions would neither occur to, nor be understood by, the average applicant. He would normally assume that the policy protected him in flights so long as he was not engaged as an airline employee. ${ }^{37}$ Since the clause could reasonably be construed in this manner, the company was held liable. Thus, on one rationale or another, courts held from the outset that passengers were not excluded by "engaged in aviation" clauses. And the later cases voice what may have been an unstated but reassuring consideration

31. E.g., First National Bank of Chattanooga v. Phocnix, 57 F.2d 731 (E.D. Tenu. 1931), decision limited on appeal to passengers who take an actual part in the control of a flight, 62 F.2d 681 (6th Cir. 1933); Travelers Ins. Co. v. Peake, 82 Fla. 128, 89 So. 418 (1921), involved fare-paying passenger; Sneddon v. Massachusetts Protective Ass'11, 29 N.M. 74, 39 P.2d 1023 (1935), involved guest passengers. Recovery was denied in each case.

32. However, when aviation clauses extended coverage to fare-paying passengers on scheduled commercial aircraft, these distinctions became all-important. E.g., Metropolitan Life Ins. Co. v. Halcomb, 79 F.2d 788 (9th Cir. 1935). See text at note 54 infra.

33. See, e.g., Swasey v. Mass. Protective Ass'n, 96 F.2d 265 (9th Cir.), ccrt. denicd, 305 U.S. 611 (1938); Goldsmith v. N.Y. Life Ins. Co., 69 F.2d 273 (8th Cir.), ccrl. denied, 292 U.S. 650 (1934) ; Tierney v. Occidental Life Ins. Co., 89 Cal. App. 779, 265 Pac. 400 (1928).

34. There were 1,451 personnel employed in $1928,1,936$ in $1929,2,740$ in 1930. CAA, Statistical Handbook of Civil Aviation 29 (1945).

35. See Masonic Accid. Ins. Co. v. Jackson, 200 Ind. 472, 164 N.E. 628 (1929).

36. 133 Misc. 780, 233 N.Y. Supp. 500 (Supp. Ct. 1929).

37. The court in Missouri Life Ins. Co. v. Martin, 188 Ark. 907, 908, 69 S.W.2d 1081, 1084 (1934), commented that if the average tradesman, artisan, or farmer-although he had many times travelled by railroad and intended to do so again-were asked whether he had engaged in railroading, he would at once answer, "No." 
in the earlier decisions-that the insured flew as a fare-paying passenger on a scheduled commercial airliner..$^{35}$

The line of cases construing the phrase "participation in aeronautics" had a far different genesis. The early judicial view, typified by Bew v. Truvclers Life Ins. Co., ${ }^{39}$ was that passengers fell within this clause. The opinion relies heavily upon dictionary definitions of both "participation" and "aeronautics", in light of these definitions the court held that an airplane passenger "partakies of the pleasure and benefits of the art of sailing or floating in the air." $\mathrm{He}$ therefore "participates" in aeronautics. Furthermore, had the intention of the parties been merely to reject liability where the insured operated the plane, "engaging in" language would have been used.11 This rationale was apparently intended to draw a line between the general acticity of flight and the specific action of flying the aircraft.

The "participate"-"engage" dichotomy established by the Brw rationale was later rejected. ${ }^{42}$ In the early 1930's the principle was advanced that aviation conditions when the policy was written, rather than judicial constructions of prior policies, was the key to parties' understanding of a particular aviation exclusion. ${ }^{43}$ Nevertheless, the opinions relied more heavily on conditions at the time of the accident. From this use of current statistics it was but a short step to the determination that while those skilled specialists who rode in a plane and were concerned with its construction, operation or manage-

38. E.g., Mutual Benefit Health \& Accid. Ass'n v. Mroyer, 94 F.2d 906 (9th Cir.), cert. denied, 304 U.S. 581 (1938) ; Hartol Products Corp. v. Prudential Ins. Co., 230 N.Y. 44, 47 N.E.2d 687 (1943).

39. 95 N.J.L. 533, 112 Atl. $\$ 59$ (1921). Accord, First Nat'l Bank of Chattanooga v. Phoenix Mfutual Life Ins. Co., 57 F.2d 731 (E.D. Tenn., 1931), decision limited on apfeal to passengers who take an actual part in the control of a fight, 62 F.2d 681 (6th Cir. 1933 ) ; Travelers Ins. Co. v. Peake, $\$ 2$ Fla. $12 \$, \$ 9$ So. $41 \$$ (1921); Meredith v. Eusinessmens Acc. Ass'n, 213 Mo. App. 68s, 252 S.W. 976 (1923).

40. Bew v. Travelers Ins. Co., 95 N.J.L. 533, 535, 112 Atl. 859, 861, (1921).

41. Ibid.

42. The Bew rationale has been rejected in a long series of decisions. E.g., Chappall v. Commercial Casualty Ins. Co., 120 W. Va. 262, 197 S.E. 723 (1938). Accord, Miass. Protective Ass'n v. Bayersdorfer, 105 F2d 595 (6th Cir. 1939); Gregory v. Mítual Life Ins. Co., 78 F.2d 522 (Sth Cir.), cert. denied, 296 U.S. 635 (1935); Martin v. Mutual Life Ins. Co., 189 Ark. 291, 71 S.W.2d 694 (1934). These decisions appear to express the current view. See Moriarity, supra note 29, at 699-700; Glass, Acronautic Risk Exclusion, 7 J. AIR L. 305, 311 (1936).

43. In Hartol Products Corp. v. Prudential Ins. Co., 290 N.Y. 44, 47 N.E.2d 697 (1934), the court held that the meaning of the clause must be construed as of the time the policy was issued. Id. at 47,47 N.E.2d at 691 . It then proceeded to undermine this holding. The parties interest was governed not by then existing decisions, but by aviation conditions at the date of contract. Id. at 50, 47 N.E.2d at 691 . Moreover, the court relied heavily on aviation statistics as of the time of the accident. Id. at 51, 47 N.E.2d at 691. Marks v. Mutual Life Ins. Co., 96 F.2d 267 (9th Cir. 1938), is a still later example of judicial reliance on the most recent aviation statistics. Thus, while pronouncing the rule that the date of contract controls the intent of the parties, the courts appear to rely far more heavily on advances in aviation techniques, which had become substantial and constant. 
ment may have participated in aeronautics, one who rode solely for the purpose of being transported as a passenger did not. Passengers were not, therefore, excluded by either "engaged in" or "participated in" language and the meaning of the two phrases coalesced. ${ }^{44}$

Abandonment of these semantic distinctions was a stride forward. Neither the dichotomy between the activity of flight and the action of flying, nor that between "engaged in" and "participated in" formed a realistic basis for assessing the sweep of aviation exclusion clauses. It is doubtful whether the distinctions reflected any real difference in the intent of the parties, and it is particularly unlikely that the average applicant had any idea of the significance of the two verbs. It is now clear that insurance companies must employ more specific language to avoid liability for passenger deaths. ${ }^{45}$

Insurers were quick to respond to the suggestion, made in Gits v. Nevv York Life Ins. Co., ${ }^{46}$ that addition of a phrase like "as a passenger or otherwise" to the exclusionary clause would render it inclusive of every airplane occupant. ${ }^{47}$ Thereafter, most insurers incorporated this additional phrase in their policies. ${ }^{48}$ Courts at first felt constrained to deny recovery, on the ground that the addition of this phrase presented a statement of the insurer's intent too clear to be overlooked or construed away. ${ }^{40}$ But this reluctance was soon overcome by a desire in many courts to protect the applicant, apparently combined with further recognition of the increased prevalence and safety of commercial airline flight.

A series of decisions beginning in the late 1930's effected a volte face which rendered the new clauses unavailing against fare-paying passengers. ${ }^{50}$ In re-

44. Missouri State Life Ins. Co. v. Martin, 188 Ark. 907, 69 S.W.2d 1081 (1934); Funk v. N.Y. Life Ins. Co., 186 Misc. 449, 60 N.L.S.2d 349 (Sup. Ct. 1946); Lee v. Guardian Life Ins. Co., 187 Misc. 221, 46 N.Y.S.2d 241 (Sup. Ct.), aff'd, 267 App. Div. 985, 48 N.Y.S.2d 800 (1st Dep't. 1944).

45. Cf. Faron v. Pa. Mutual Life Ins. Co., 179 F.2d 480 (3d Cir. 1948) (fare-paying passenger not excluded by clause stating that double indemnity would not be paid ". . . if the death of the insured resuited directly or indirectly ... from aeronautic ... casualty. ..."). See McDaniel v. California-Western States Life Ins. Co., 181 F.2d 606 (5th Cir.), cert. denied, 340 U.S. 822 (1950) (no liability for death of Navy flier under clause stating "as a result of travel or flight in or upon any kind of aircraft, or from falling or otherwise descending therefrom or therewith during said flight.")

46. 32 F.2d (7th Cir.), cert. denied, 280 U.S. 564 (1929).

47. Id. at 10 .

48. The new clauses, therefore, typically consisted of the original "engage in" or "participate in" language with the additional clause tacked on. See Kremlick, Adjudicated Aviation Clatises in Life and Accident Contracts, 25 Micr. STATE B.J. 37, 46-7 (1946).

49. E.g., Goldsmith v. New York Life Ins. Co., 69 F.2d 273 (8th Cir.), ccrt. denicd, 292 U.S. 650 (1934) (insured passenger died in plane crash); Mayer v. New York Life Ins. Co., 74 F.2d 118 (6th Cir. 1934) (recovery denied on similar facts); Christen v. Now York Life Ins. Co., 19 F. Supp. 440 (N.D. Ill. 1937) (same).

50. Phoenix Mutual Life Ins. Co. v. Flynn, 171 F.2d 982 (D.C. Cir. 1948) construed "participating in aeronautics, as a passenger or otherwise" in favor of the insured. The court reasoned that passengers did not participate in aeronautics and then rejected the contention that "as a passenger or otherwise" effectively expanded the exclusion to one who 
versing their field, courts relied on the theory that the new clause was ambiguous. Its terms, they thought, applied to activities in which a passenger could conceivably participate or engage. Since airline passengers did not participate or engage in aeronautics, the extension of the exclusion did not clearly apply to them. And because the meaning of the clause to the average policyholder was controlling and he, upon taking a casual flight, would not consider himself excluded, the phrase was ambiguous. Consequently it must be construed against the insurer, allowing recovery..$^{51}$ This tenuous rationale-which ignores the policy's language ${ }^{52}$-was thought warranted by the injustice of denying recovery on the basis of an isolated flight. This feeling of injustice sprung from a belief that people cannot be expected to read and understand insurance contracts, and therefore deserve special judicial protection. ${ }^{33}$

Yielding to judicial hostility, insurers in the late 1930's extended coverage to fare-paying passengers on "regularly scheduled airlines." This extension was apparently built on the fact that such passengers are protected by Governmental regulations reducing the risk of flight. ${ }^{65}$ Thus, increased risks are

has no relation to the flight other than as a mere passenger. Accord, Day v. Equitable Life Assur. Soc'y, 83 F.2d 147 (10th Cir.), cert. denied, 299 U.S. $54 S$ (1936); Sun Life Assur. Co. v. Kiester, \&3 Ga. App. 87, 62 S.E.2d 660 (1950) ; Provident Trust Co. v. Equitable Life Assur. Society, $316 \mathrm{~Pa}$. 121, 172 Atl. 701 (1934) ; National Bank of Commerce v. New York Life Ins. Co., 181 Tenn. 299, 181 S.W.2d 151 (1944). See also Moriarity, supra note 42, at 702. While some of these decisions overlap in time with those giving effect to the clause, the bulk of them fall in later years. And since 1940 or therebouts the view that more specific language is, necessary to exclude passenger fight has become controlling. Cf. Moriarity, suspra note 29 , at 702 .

51. This line of reasoning was put forward in Hartol Prod. Corp. v. Prudential Ins. Co., 290 N.Y. 44, 47 N.E.2d 687 (1943) (where a policy excluded death from having bren eargaged, as a passenger or otherwise in aviation or aeronautics). The court felt that the average policy-holder would not consider himself excluded if he took an isolated airplane flight as a fare-paying passenger. It took notice of the sixfold improvement in the safety of air travel between issuance of the policy and the insured"s death on the theory that this improvement cast light on the insured's state of mind. Id. at 50, 51, 47 N.E. $2 d$ at 691 . Accord, Lee v. Guardian Life Ins. Co., 187 2fisc. 221, 46 N.Y.S.2d 241 (Sup. Ct), aff'd mem., 267 App. Div. 985, 48 N.Y.S.2d 800 (1st Dep't 1944).

52. The use of "as a passenger or otherwise" was obviously intended to malie the insurer's meaning crystal clear.

53. See Schultz, The Special Nature of the Insurance Controct: A Few Suggestions for Further Study, 15 LAW \& Contexr. Prob. 376, 379 (1950); Vare, Husinsoos of THE LAw of INSURANCE 215 (2d ed. 1930), for a discussion of the finding that the public at large, and some courts, acknowledge the prevailing business custom of even careful businessmen not to read their policies but to rely on the accuracy, slill and good faith of the agent. For a discussion of problems of judicial construction raised by this attitude, see Kessler, Contracts of Adhesion-Sone Thoughts Allout Frecdom of Contract, 43 CoL. L. Rev. 629 (1943).

54. See Moriarity, stipra note 29, at 703.

55. See Society of Actuaries, Transactions 58 (April, 1953). Federal regulation of aviation is carried out by two agencies, the Civil Aeronautics Administration (CAA) and the Civil Aeronautics Board (CAB). The CAB prescribes the Civil Air Regulations, which deal with the competency of airmen, airworthiness of craft, and air traffic control. 
avoided and standard premium rates made applicable. And at least one consequence of this retreat has gratified insurers: courts have tended to construe the exception rigidly. ${ }^{56}$ Where no fare-paying obligation exists between the carrier and the insured, recovery is denied. ${ }^{57}$ Similarly, if the flight was not one regularly scheduled between definite terminals, no liability is imposed..$^{\text {to }}$

Since most civilians are fare-paying passengers whenever they fly, the requirement that the flight be scheduled is, for them, the crucial one. ${ }^{50}$ The clause clearly extends the exclusion to flights in small non-commercial aircraft. ${ }^{60}$ However, courts have extended it beyond this limited group, repeatedly holding that flight on commercial non-scheduled airlines which fly on a charter rather than a timetable basis is also excluded. ${ }^{61}$ Furthermore, where the insured dies in a plane chartered from an airline operating a regularly scheduled route, his beneficiary cannot recover. ${ }^{62}$

Where the insured was killed in the flight of a military transport, the beneficiary must hurdle the additional barrier imposed by the fare-paying restriction. Thus, in Burns v. Mutual Life Ins. Co., ${ }^{63}$ the insured was killed in a

It promotes safety by certifying airmen, aircraft, and agencies such as flight and ground schools, and checks the design, structure and performance of new planes. CAA, STAtistical HandBook of Civil Aviation 1 (1953).

56. E.g., Metropolitan Life Ins. Co. v. Halcomb, 79 F.2d 788 (9th Cir. 1935) (no fare-paying obligation existed between insured and a pilot holding only a private license, because pilot not permitted to transport persons for hire); Krause v. Pacific Mlutual Life Ins. Co., 141 Neb. 844, 5 N.W.2d 229 (1942) (insured who held trip pass and paid nominal fee for ticketing expense excluded from coverage); Padgett v. Metropolitan Life Ins. Co., 206 N.C. 364, 173 S.E. 903 (1934) (insured, guest passenger, killed while riding with employer who had a private license).

57. E.g., Metropolitan Life Ins. Co. v. Halcomb, 79 F.2d 788 (9th Cir. 1935) ; Padgett v. Metropolitan Life Ins. Co., 206 N.C. 364, 173 S.E. 903 (1934).

58. E.g., McBride v. Prudential Ins. Co., 147 Ohio St. 461, 72 N.E.2d 98 (1947) (insured contracted with company operating commercial airplanes for the use of a plane to transport him to specified place on hunting trip). Cf. Hyfer v, Metropolitan Life Ins. Co., 318 Mass. 175, 178, 61 N.E.2d 3, 4 (1945) ("A scheduled flight" on an Army transport plane was not "a scheduled passenger air service regularly offered between specified airports.").

59. There still remains, however, the possible exception of a passenger travelling on a regularly scheduled flight with a trip pass. See, e.g., Krause v. Pacific Mutual Life Ins. Co., 141 Neb. 844, 5 N.W.2d 229 (1942) (even though insured was compelled to pay a nominal amount, under controlling regulations, to defray cost of ticketing, passenger supplies, etc., he was held not to be a fare-paying passenger).

60. E.g., Provident Life and Acc. Ins. Co. v. Anderson, 166 F.2d 492 (4th Cir.), cert. denied, 334 U.S. 846 (1948) ; Weisman v. Guardian Life Ins. Co., 67 N.Y.S.2d 604 (Sup. Ct. 1946), aff'd memo. op., 273 App. Div. 761, 75 N.Y.S.2d 653, 654 (1st Dep't 1947).

61. Sulzbacher v. Travelers Ins. Co., 137 F.2d 386 (8th Cir. 1943); Brown v. Pacific Mut. Life Ins. Co., 8 F.2d 996 (5th Cir. 1925) ; No. Amer. Accident Ins. Co. v. Pitts, 213 Ala. 102, 104 So. 21 (1925). Accord, Wendorff v. Missouri State Life Ins. Co., 318 Mo. 363, 1 S.W.2d 99 (1927); Meredith v. Business Men's Accident Ass'n, 213 Mo. App. 688, 252 S.W. 976 (1923).

62. McBride v. Prudential Ins. Co., 147 Ohio 461, 72 N.E.2d 98 (1947).

63. 79 F. Supp. 847 (W.D. Mich., 1948), aff'd, 179 F.2d 236 (6th Cir. 1949). 
military plane during a domestic flight between Army air bases, and recovery was denied. The insured did not pay the regular commercial fare. In addition, the insured was not "in the course of transportation from one definite terminal to another," and the flight was therefore not "scheduled." But in Quinones v. Life and Casualty Ins. Co., ${ }^{\text {b5 }}$ insured, a Medical Corps doctor, was lilled under similar circumstances and recovery was allowed. The court held that the doctor was a "fare-paying" passenger. The Army provided transportation for which the Government paid; the fact that the decessed did not part with his own money was thought immaterial. And the flight, reasoned the court, was regularly scheduled by the Air Force between established airports in a plane regularly operated by the United States. While this result may be desirable, it is in conflict with the great majority of recent decisions following Burns. ${ }^{68}$

\section{Actuarial Facts}

Since aviation exclusion clauses rest on the assumption of increased rish, restrictions on insurer liability are valid only to the extent supported by actuarial statistics. While rigid exclusions have declined as an insurer practice, the use of broad excludable categories continues. Insurers' practices both as to pilots and passengers are divided, in order of willingness to accept, by scheduled, non-scheduled and military flight classifications. ${ }^{\circ 7}$ And few distinctions are drawn within the last two categories between types of flight. The validity of these distinctions, as well as the older exclusions still enforced by

64. 79 F. Supp. 847, 854 (W.D. Mich. 1948). The court also concluded that the plane was not, at the time of the accident, "in charge of a licensed pilot," since the term licerased pilot means one licensed by the CAA to pilot a plane carrying passengers for hire. Accord, Richardson v. Iowa State Traveling Mien's Ass'n, 228 Iowa 319, 291 N.W. $408(1940)$.

65. 209 La. 75, 24 So.2d 270 (1945).

66. E.g., Greene v. Mutual Benefit Life Ins. Co., 144 F.2d 55 (1st Cir. 1944) ; Continental Life Ins. Co. v. Newman, 219 Ala, 311, 123 So. 93 (1929); Knouse v. Equitable Life Ins. Co., 163 Kan. 213, 181 P.2d 310 (1947) ; Hyfer v. Mletropolitan Life Ins. Co., 318 Mass. 175, 61 N.E.2d 3 (1945).

67. A recent study of the practices of one hundred insurance companies, as of 1948 , reveals the prevailing attitude of insurers. No company was willing to grant unrestricted coverage to pilots of any sort. However, most companies were willing to insure pilots on scheduled airlines subject to higher premiums and restrictions on policy amount. Nonscheduled fliers fare worse. Fifteen to 20 companies had no practice of accepting these pilots, and the remainder imposed more stringent restrictions than on scheduled pilots. Military pilots faced the greatest reluctance to insure. Thirty-two companies had no prastice of accepting them, while the remainder employed restrictions similar to thuse imposed on non-scheduled pilots.

Today, 83 of the 100 companies are willing to insure applicants without any restrictions as to flight on a regularly scheduled airline. An additional 12 companies will insure with higher premiums. In sharp contrast, only 50 companies express a willingness tw insure flight on non-scheduled airlines, and only half of these will do so without restrictions. Passengers on military flights are least likely to be covered. Of the 23 companies expressing a willingness to insure them, only 14 would du so without restrictions, while 
the courts, stands or falls on the statistics. If they fail to support these categorizations of flight risks, the system presently employed must be revamped.

\section{Pilot and Crew Member}

While the basic pilot-passenger distinction is well founded, ${ }^{08}$ modern avintion requires that underwriters make a further breakdown of the "pilot" category. Civilian and military pilots should be divided into separate categories for insurance treatment. ${ }^{60}$ And further subdivision within the civilian group is warranted by recent actuarial reports. ${ }^{70}$ Non-commercial pilots with under 100 solo hours in the preceding year have a death rate significantly lower than any other group. ${ }^{71}$ On the other hand, those employed as nonairline pilots have the highest mortality. ${ }^{72}$ Scheduled airline pilots as a group, and persons holding commercial or transport licenses but flying only for pleasure or on personal business, fall between the two extremes. ${ }^{78}$ Members of the latter group with over 100 solo hours have the highest of the intermediate death rates. ${ }^{74}$

The same study shows that the lowest death rate for any group of military

13 would not insure such passengers under any conditions. INSTITUTE of LiFE INSURANCE, Summary of Practices of 100 U.S. Life Insurance Companies (n.d.).

For a suggestion that some increased coverage, especially regarding military pilots, has taken place since 1948, see communication to the YALE LAW JouRNAL from Albert Hermalin, Ass't Statistical Dir., Inst. of Life Ins., dated March 18, 1954, in Yale Law Library.

68. The passenger death rate per 1000 passenger hours in 1951 was .0024 while that for the fiirst pilots was .0036. Society of Actuaries, Transactions 57 (April, 1953).

69. A study of the experience of 29 companies over a five year period showed a higher death rate for military civilian pilots. Id. at 67 et seq. See notes 77,79 infra. 70.

INTERCOMPANY EXPERIENCE-PILOTS

29 CoMpanies, 1946-1951*

\begin{tabular}{lc}
\hline & $\begin{array}{c}\text { Rate per 1000 } \\
\text { years exposure }\end{array}$ \\
\hline $\begin{array}{l}\text { Scheduled Air Line Pilots } \\
\text { Pilots with commercial or Transport License } \\
\text { but employed as non-civilian pilots } \\
\text { Pilots with commercial or Transport License } \\
\quad \text { flying for pleasure or personal business } \\
\quad \text { Over 100 solo hours }\end{array}$ & 2.64 \\
$\quad$ Under 100 solo hours & 6.20 \\
Non-commercial with under 100 solo hours & 3.38 \\
\end{tabular}

* Author's condensation of data in Society of Actuarues, Transactions 67-8 (April 1953).

71. Ibid

72. Ibid.

73. Ibid.

74. Ibid. 
pilots approximates the highest civilian mortality rate. ${ }^{7 \mathrm{E}}$ But the divergence of rates among military groups was far greater than the difference between the several civilian categories. ${ }^{70}$ With combat missions excluded, there was an inverse ratio between pilot age and the mortality rate. Thus, the highest death rate was found among pilots under 25 years of age.77 Aside from age and experience factors, ${ }^{78}$ distinctions can be drawn according to duty assignment and type of aircraft flown. Thus, jet pilots have by far the highest death rate, followed by fliers of single and six engined aircraft. ${ }^{70}$

75.

U.S.A.F. on Active DUty: Aviation Death Rate per 1000 YEARS OF EXPOSURE

\begin{tabular}{cc}
\hline \hline & $19.47-51$ average raic \\
Age & 1000 years \\
\hline Under 25 & 19.0 \\
$25-29$ & 10.7 \\
$30-34$ & 6.1 \\
35 and over & 5.4 \\
\hline
\end{tabular}

* Combat missions excluded.

$\div$ Author's condensation of data in Societr of Actunies, TransacTroNs 5S-9 (April, 1953).

76. Ibid.

77. Ibid.

78. The average death rate for student pilots taling a basic training course, 1949 1951, was 5.1 per 1,000 years of exposure, and that for the advanced course was 14.3 per 1,000 years of exposure. Soctety of Actuaries, Traxsactionis 66 (April, 1953). These figures, when compared to the age and death rate figures sispra note 76 , may indieate that age is a lesser factor than duty assignment. Pilots in basic training fly the caiest type of aircraft and have the lowest death rate.

79.

Deates in Non-Coxbat Amcraft Accinents of ail. Rated U.S.A.F. Pilots Classified By DUTY Assignzentrs*

\begin{tabular}{lc}
\hline & Deafh Ratc \\
Duty Assigmment & 1000 years Exporurc \\
\hline Jet fighter & 39.8 \\
All-weather & 28.5 \\
Six-engine & 25.9 \\
Single-engine & 25.1 \\
Tactical reconnaissance & 13.0 \\
Four-engine & 10.4 \\
Double-engine & 9.3 \\
Operations officer & 8.6 \\
Not assigned primarily to flight duty & 4.5 \\
\hline
\end{tabular}

* Soctetr of Actuartes, Transactions 61 (April, 1953). The Society noted that $86 \%$ of the deaths in a type aircraft appropriate to the duty assignment and that a pilot might have more than one duty assignment a year. Ibid. It is obvious from a compracicon with the 9.5 death rate for "all pilots," id. at 59 , that a considerable propartion of pilots are not assigned primarily to flying duty at any given time. 


\section{The Passenger}

The distinction as to passenger exclusion based on scheduled versus nonscheduled flight is unsupported by the evidence. ${ }^{80}$ Different types of nonscheduled flight require different treatment; Non-scheduled Irregular Carriers ${ }^{81}$ which operate transport aircraft are very different from local charter flying services, or pleasure or instructional flying. ${ }^{82}$ As a result of closer federal control as well as self-regulation, Domestic Irregular Carriers had by 1953 achieved an 0.7 death rate per 100 million passenger miles, which almost matches the 0.6 rate of domestic passenger service on scheduled airlines. ${ }^{84}$ The probability of fatal accidents therefore remains a significant underwriting factor only as to other categories of non-scheduled flights.

The exclusion of passengers on military flights is equally unsupported by current statistics. As a result of high maintenance and crew training standards, the Military Air Transport Service's 0.9 death rate per 100 million passenger miles for 1947-1951 compares more than favorably with the 1.5 rate of scheduled civilian airlines. ${ }^{85}$ It is far better than the rate achieved by the latter in transporting military passengers. ${ }^{86}$

80. Scheduled domestic passenger operations by United States Certified Air Carricrs in 1953 accounted for 30.7 million passengers and 15.4 billion passenger miles. $A$ total of 86 passenger fatalities occurred; the fatality rate was 0.6 per 100 million passenger miles flown. Domestic common carriage and charter passenger services (non-military) of the U.S. Large Irregular Air Carriers flew 481 thousand passengers and 675 million passenger miles with only 5 passenger fatalities occurring for a fatality rate of 0.7 per 100 million passenger miles. CAB, Bulletro 54-12 (Feb. 18, 1954). For a table indicating the gradual decline in aviation death rates since World War II, see CAB, CoMmArAtive Safety Statistics Part II, 2 (Aug. 15, 1953).

81. The $C A B$ delineates commercial air transport operations in two broad categorics: Certified Air Carriers (i.e., scheduled), and Large Irregular Air Carriers. See CAB Bultetin, note 80 supra. Large Irregular Carriers form one sub-category of the "nonscheduled" classification used by the Society of Actuaries which includes Non-Commercial Business (flying in large aircraft maintained by corporations for transportation of officers and employees on company business), Commercial Miscellaneous, Personal (pleasure), and Instructional. Society of Actuaries, Transactions 55 et scq. (April, 1953). The Irregular Carriers include all those with transport aircraft of over 12,500 pounds gross weight. Id. at 57.

82. Ibid.

83. The regulations of the Civil Aeronautics Board and the Civil Aviation Administration are collected in 14 CODE FED. REGS. cc. 1-2 (rev. 1952).

84. CAB, Bulletin, note 80 supra.

85. Society of Actuaries, Transactions 62 (April, 1953). These figures are based on the five year period 1947-1951. While figures for this period reflect a higher civilian death rate than for any other postwar period, this does not affect the overall comparison. For no 5 year postwar period have civilian fatalities fallen below the 0.9 figure for Military passenger flights. The lowest unweighted average for scheduled civilian flights is 0.94 for $1949-53$ and the $1946-53$ average is 1.3. CAB, Comparative Safety Statistics Part II, 1. (Aug. 15, 1953); CAB, Bulletin 54-12 (Feb. 18, 1954).

86. Military passenger operations of certified carriers for 1953 (including Civil Air Movements) accounted for 406,000,000 passenger miles flown. There were 21 passenger fatalities (one domestic accident); the death rate was 5.2 per 100 million passenger miles. CAB, Bulletin 54-12 (Feb. 18, 1954). 
Today's statistics show that indiscriminate lumping of pilots and passengers into a few broad categories is grossly inadequate. While at one time these categories may have reflected actual experience, their continued use does not. Neither civilian nor military fliers can be treated as single groups; risk factors vary widely within each group. Similarly, the actuarial facts indicate that many distinctions drawn on the basis of fare-payment or the scheduled character of flight are unwarranted. By granting coverage to passengers on scheduled civilian flights, insurers have tacitly admitted that the death rate involved is an insignificant underwriting factor. ${ }^{57}$ Since the military rate is lower than the civilian, it follows that exclusion of passengers on domestic military flights is unjustified. For the most part, passengers on military aircraft and those on scheduled or large irregular civilian flights bear the same risks, and restricted coverage is necessary only with regard to passengers on other non-scheduled craft and the military passenger services of the civilian airlines.

\section{CONCLUSION AND RECOMIIENDATIONS}

Life insurance is today more important to the economic welfare of millions of people than in any previous generation. ${ }^{8 s}$ Therefore, insurance companies should revamp their policies, and courts, in construing them, should harmonize their doctrines with changed aviation conditions. ${ }^{89}$ Restrictions, to be justifiable, must represent an honest appraisal of existing hazards, grounded on sound underwriting criteria. A detailed classification on the basis of actuarial data is essential.

These data demand substantial modification of passenger restrictions. Since passenger risks fall into two categories, policy restrictions should do likewise. Irregular Carrier \& Military passengers should receive the same treatment as those who fly on scheduled lines. And policies containing flight risk exclusions should offer extended coverage for all types of non-scheduled flight at

87. This treatment of airline passengers by the companies is clearly warranted by the fact that the death rate for travel in automobiles and taxis, for which there is no exclusion, exceeds the rate for scheduled or non-scheduled air transportation. Sce table, note 8 supra.

88. In 1952, 219 million policies protected 88 million holders. The average coverage per policyholder has risen from $\$ 780$ in 1902 , to $\$ 3,100$ in 1952. Ixst. UF Life I::s., LIFE Insurance Fact Book 5 (1953). Three out of every four families own life insurance. Id. at 7 . During 1952, total benefit payments exceeded \$4 billion for the first time and were $\$ 1.7$ billion greater than in 1942. Ownership is not confined solely to higher income groups. Sixty percent of the families in the \$1000 to $\$ 1999$ annual income class own life insurance. Id. at 13 . Twenty-nine percent of the familics put $5 \%$ or more of their disposable income into life insurance premiums. Id. at 15.

89. Courts can do this-as they have in the past-by finding cxclusionary clauses ambiguous, since the insured would have been justified in assuming he was not excluded because statistics on the safety of air passenger flight would not support an exclusion. See, e.g., cases cited in notes 43,51, and accompanying text. See also Lachs v. Fidelity \& Casualty Co., 281 App. Div. 633, 121 N.Y.S.2d 230 (1st Dep't 1953), aff'd, No. 221, Ct. App., March 4, 1954. 
increased premium rates. If the applicant accepts the extended coverage the company will be bound. If he rejects it and subsequently dies on an excluded flight, the insurer will incur no liability.

Moreover, blanket pilot exclusions should be scrapped and systematic subcategorization substituted therefor. Restrictions and rate adjustments for civilian pilots should be determined by the type and frequency of flight, while for military fliers classification based on pilot's age and type of craft flown should, whenever practicable, be substituted for nondiscriminating categorization. Some insurers are currently making these distinctions, ${ }^{00}$ and the remainder should follow suit.

By formulating their restrictions within this framework, insurers will avoid the adverbial and prepositional monsters of the past. The insured's activity should be listed in the policy together with a clear statement of the degree to which coverage is restricted or rates increased. In addition, all applicants should be given actual notice of the company's rates, limitations, and exclusions of aviation risks, and how these rules affect them. The applicant should be impressed with his duty to notify the insurer whenever his flight risk status changes. Should he fail to do so and subsequently die as a result of a more hazardous activity, the policy will be void. ${ }^{.1}$ Similarly, if the insured's status becomes less hazardous he should, upon notice to the company, became eligible for a reduction in premiums. ${ }^{92}$ Past litigation has indicated that by expanding coverage, insurers are better able to obtain enforcement of retained restrictions. ${ }^{93}$ And a rationalization of coverage founded upon current aviation statistics will adequately protect the legitimate business interests of insurers while granting maximum protection to beneficiaries.

\section{Stanley P. Wagman $\dagger$}

90. For an example of one company's recognition of the necessity of this approach see, The Unrted, presented by United Services Life Insurance Co., Washington, D.C. The monthly allotment premium rates contain extra premium for aviation risks. Pilots and crewmembers pay $\$ 5.00$ extra with the exception of all fighter pilots, USAF Occupational Specialists, and Navy Aero. Eng. Duty Officers, who pay an extra $\$ 15, \$ 2, \$ 2$ respectively. Id. at 7 .

91. It is reasonable to place this burden on the insured in light of the increased coverage that would be available to him at all times upon his proper performance of the contract.

92. Assuming that investigation bears out the insured's contention, the company will fix a new premium rate. This rate shall be effective from the date of notice. But if administrative costs for refunding any excess paid for the premium period during which the change occurred are prohibitive, then such amount shall be credited to the insured's favor at the next premium anniversary

93. See page 702 supro.

$\dagger$ Member, Class of 1954, Yale Law School. 